\title{
PROKLAMASI MENURUT MOHAMMAD YAMIN: BERDAULAT DAN BERKONSTITUSI
}

\author{
Jimly Asshiddiqie \\ Fakultas Hukum Universitas Indonesia
}

Awaludin Marwan

Fakultas Hukum Universitas Bhayangkara Jakarta Raya

\begin{abstract}
ABSTRAK
Pemikiran Yamin pada masa kemerdekaan memandang proklamasi bukan hanya sebuah teks deklarasi kemerdekaan. Melainkan sebuah simbol filsafat hukum bahwa Indonesia telah merdeka. Dengan kata lain, proklamasi adalah bagian dari sumber hukum yang patut dirujuk dalam sistem ketata-negaraan. Karena proklamasilah yang mengawali sebuah kedaulatan dan inspirasi lahirnya konstitusi dasar.
\end{abstract}

Kata Kunci: proklamasi, Yamin, kemerdekaan, sumber hukum

\begin{abstract}
Yamin's thought in the time of independence, seeing that proclamation is not only a text of independence declaration. But it is also a symbol of legal philosophy that mentioning Indonesia was already independence. On the other words, proclamation is a part of legal course which deserved to be quoted in the government system. Hence, proclamation is known as the inspiration of sovereign constitutional country.
\end{abstract}

Keywords: proclamation, Yamin, independence, legal source

\section{PENDAHULUAN}

Kumandang proklamasi 17 Agustus 1945 adalah gunungan es yang pecah dari keinginan besar bangsa Indonesia, yang melahirkan gumpalan teks peradaban bernama konstitusi. ${ }^{1}$ Lantaran proklamasi, Yamin ditangkap bersama tokoh pergerakan nasional yang lain. Dicap sebagai nasionalis fanatis (nationalistische

\footnotetext{
${ }^{1}$ Muhammad Yamin. Proklamasi dan Konstitusi Republik Indonesia. (Jakarta: 1951, Penerbit Djambatan)., p. 82
} 
fanatici). ${ }^{2}$ Dituduh makar oleh pemerintahan Belanda dan bersekongkol polisi rahasia Jepang, Nishida. ${ }^{3}$ Dianggap melakukan tipu muslihat dengan barisan pemuda Indonesia yang dipersenjatai, ${ }^{4}$ terlalu bersikukuh konyol tidak hendak melepaskan Hindia dari penguasa Jepang kepada pangkuan haribaan pemerintah kolonial Belanda. ${ }^{5}$

Proklamasi kemerdekaan adalah sebuah tindakan treatikal separatis, yang oleh pihak pemerintah Belanda sungguh dibenci. Dalam sebuah sidang di parlemen Belanda (Tweede Kamer) yang diikuti oleh 61 anggota parlemen dan menterimenteri (Menteri dalam negeri (Minister van Binnenlandsche Zaken), Menteri Luar Negeri (Minister van Buitenlandsche Zaken), Menteri Ekonomi (Minister van Financiën), Menteri Sosial (Minister van Sociale Zaken, dst) pada tanggal 17 Oktober 1945, adalah anggota Parlemen van Poll bersuara keras. Ia menyulut kemarahan dengan dalih sekitar 50.000 perempuan Belanda bermukim di Batavia dikelilingi oleh pemuda Indonesia yang bersenjata. ${ }^{6}$ Sehari sebelumnya, sidang parlemen Belanda yang diisi oleh laporan Logeman Menteri Daerah Jajahan (Minister van Overzeesche Gebeidsdeelen) menceritakan paska proklamasi masyarakat Indonesia diselimuti dengan sikap penuh kebencian terhadap ras kulit putih (volgegoten met blankenhaat). ${ }^{7}$

Kendatipun demikian, Yamin tetap bersikukuh pada proklamasi. Proklamasi dan konstitusi bagai dua keping logam yang tak bisa terpisahkan. Proklamasi adalah sebuah penisbatan politik, sementara konstitusi adalah magnum opus para jenius nusantara. Bagi Yamin, kemerdekaan Indonesia, bukan setelah penyerahan

\footnotetext{
${ }^{2}$ Batavia Komt tot Kalmte. On Noorden. Pada tanggal 9 September 1945

3 De Betoging van Soekarno. Dagblad Amigoe di Cuacao pada tanggal 29 September 1945. Soekarno juga pada saat itu ditangkap oleh pemerintah Sekutu dan Belanda yang kemudian segera dilepaskan. Pengamanan Soekarno dan tokoh nasionalis yang lain termasuk Yamin yang ditulis dalam berita itu sebagai advokat yang terlibat dalam proses makar (proklamasi), ialah upaya untuk meredam gelombang massa yang melawan pemerintahan sah versi Belanda.

${ }^{4}$ Rustige Nacht in Batavia, Strijdend Nederland, pada tanggal 25 September 1945.

${ }^{5}$ Leuwarder Koerier. Bezetting van indie versneld. Pada tanggal 25 September 1945.

${ }^{6}$ Handelingen Tweede Kamer 17, pada tanggal 17 Oktober 1945. Membahas pada pokoknya pembaharuan undang-undang tentang daerah-daerah jajahan dan secara khusus soal HindiaBelanda. Hadir juga PFM Cremers sebagai pejabat pendaftaran kasus di pengadilan Hindia-Belanda. Namun dalam rapat ia tidak tercatat berbicara apapun soal Hindia.

${ }^{7}$ Handelingen Tweede Kamer 16, pada tanggal 16 Oktober 1945. Sidang dilaksanakan pada hari Rabu, pada tanggal 16 Oktober 1945, dipimpin oleh van Schalk. Rapat secara khusus membahas soal situasi perkembangan di Hindia, yang menghadirkan perwakilan langsung kerajaan. Dan, pada waktu itu akan memutuskan sikap resmi pemerintah kolonial Belanda terhadap situasi Indonesia, termasuk di bidang bisnis dan perusahaan-perusahaan Belanda.
} 
kedaulatan RI-Belanda tahun 1949, melainkan sejak disyairkannya proklamasi 1945. Sebab dalam proklamasi itulah lantunan maklumat kedaulatan yang ditandai juga dengan menyingsingnya konstitusi. Menghormati Indonesia, maka hormati dulu konstitusi yang sudah diproklamirkan.

Satu daripada berpuluh-puluh sembojan jang ditulis sekeliling tanggal 17 Agustus itu dengan segala kehormatan pada dinding-dinding jang berdiri atau pada kereta-api jang bergerak diseluruh pulau Djawa dan jang sangat menusuk otak dan perasaan jalah: Respect our Constitution, August 17 Hormatilah Konstitusi kami tanggal 17 Agustus! ${ }^{8}$

Dalam bukunya yang berjudul 'Proklamasi dan Konstitusi Indonesia,' Yamin menyebutkan bahwa slogan tersebut ditulis dalam bahasa Inggris. Kenapa ditulis dalam bahasa Inggris? Sebab, menurut Yamin, adanya kesinsyafan para pemuda terhadap kadaan politik international setelah runtuhnya Tokyo dan munculnya kekuatan pemenang Anglo-Amerika. Yamin juga mencatat Jenderal perang Inggris Panglima Mountbatten juga sudah menyerukan pendaratan pasukan ke Nusantara. Slogan tersebut adalah sebuah tantangan pada pihak internasional untuk menghormati konstitusi Republik.

Teks konstitusi itu memang mempunyai sistem yang terintegrasi dengan kehidupan ekonomi, politik, pendidikan, sosial, kebudayaan dan utamanya motor dari sistem hukum. ${ }^{9}$ Maka topografi konstitusi bukanlah tumpukan 'aturan' saja, melainkan juga terkandung tata nilai dan dentingan cita ideal yang utopis. ${ }^{10}$ Konsitusi adalah doktrin cita rasa keadilan sebuah masyarakat, yang menjadi pembatas dan pagar dengan institusi hukum international. ${ }^{11}$ Sementara konstitusi

\footnotetext{
${ }^{8}$ Muhammad Yamin. Proklamasi dan Konstitusi Republik Indonesia. (Jakarta: 1951, Penerbit Djambatan)., p. 25

9 Ronald Dworkin. Freedom's Law: The Moral Reading of the Amerian Constitutions. (Oxford: Oxford University Press, 1991). p. 9-11. Di Amerika umpamanya, meskipun konstitusi pertama dibangun dengan banyak aneka macam persoalan, seperti rasisme. Namun tak lantas membuat konstitusi pertama tidak bermakna. Pada amandemen konstitusi berikutnya, misalnya yang keempat belas pada tanggal 9 Juli 1869 disahkannya, segregasi rasial coba untuk dipecahkan dan merujuk pada konstitusi awal mula Amerika.

${ }^{10}$ Jeremy Waldron. Ronald Dworkin: An Appreciation. New York University School of Law Paper Working No. 13-19., Juli 2013.

${ }^{11}$ Ronald Dworkin. Justice in Robes. (Harvard: The Belkpan Press of Harvard University Press, 2006)., p. 107-8. Dworkin menyebutkan konstitusilah yang menggaransi status setiap warga yang seharunys mendapat sekuritas sosial, dengan asuransi kesehatan, bantuan tempat tinggal yang layak, pekerjaan yang memadai, dst. Konstitusi lebih lanjut menyerukan bahwa setiap insan warga negara itu mempunyai kesamaan kedudukan di depan hukum dan negara.
} 
itu sendiri, disuntik ruhnya ruhnya oleh proklamasi. Menurut Yamin 'ditinjau dari pihak hukum maka proklamasi itu ialah suatu 'source of the soucers' atau dasar dari pada segala dasar ketertiban baru di tanah indoensia semenjak 17 Agustus 1945. ${ }^{12}$

Barangkali proklamasi adalah sebuah metapolitik. ${ }^{13}$ Sebuah diktum yang diucapkan sekali, namun sebagai pertanda, ada sebuah zaman baru. Sebuah zaman yang dirumuskan oleh Soekarno, Hatta, Yamin, Soepomo, Agus Salim, Wahid Hasyim, dan para tokoh yang lain sebagai Republik berdaulat. Dalam sebuah proses yang dinamakan revolusi oleh para tokoh ini, proklamasi menduduki peristiwa yang penting. Proklamasi sebagai salah satu jantung dari mengawali sebuah revolusi, saat para Kempetai (polisi Jepang) mengultimatum pelarangan keras pengibaran bendera merah putih. Namun tokoh-tokoh nasional bersikeras mengibarkannya, bahkan sempat bertahan hingga 6 (enam) minggu sebagai simbol kemerdekaan. ${ }^{14}$

Bagi Yamin, proklamasi bukan hanya simbol kemerdekaan. Akan tetapi sebagai sebuah tindakan menerjemahkan aspirasi rakyat Murba Indonesia. Seperti yang digambarkan dalam pengantar bukunya 'Proklamasi dan Kemerdekaan Republik Indonesia.'

'Mendjelaskan isi Piagam dan Proklamasi berarti melukiskan ketetapan hati Murba Indonesia, supaja Revolusi dan Mahajuda Kemerdekaan itu berhasil penuh mentjapai kemenangan dalam menegakan Republik Indonesia atas kemerdekaan

\footnotetext{
12 Muhammad Yamin. Proklamasi dan Konstitusi Republik Indonesia. (Jakarta: 1951, Penerbit Djambatan)., p. 24-25.

13 Alain Badiou. Metapolitics. (London: Verso, 2006), p. 11-15. Ialah sebuah upaya untuk mengembalikan telos politik dalam sebuah pencarian kebenaran, bukan semata-mata hitunghitungan untung rugi politik. Metapolitik bisa diartikan memahami politik sebagai sebuah pemikiran, setelah alam dialektika gagasan sudah dibungkam dengan sistem birokrasi, pemilu, dan administrasi yang membuat manusia menjelma menjadi robot dan tunggangan kapitalisme. Bagaimana kita melihat tulisan-tulisan yang berkembang pada masa gerakan nasional kemerdekaan, bagaimana pula kita membaca risalah-risalah dokumen tentang perdebatan fundamental tentang dasar negara dan bentuk negara, para terpelajar menyusun kapital dengan menggali sedalam mungkin sari sejarah nusantara.

${ }^{14}$ Beberapa hubungan baik dengan perwira Jepang yang mendukung kemerdekaan cukup membantu dalam proses proklamasi ini. Meskipun, Jepang dengan polisinya Kempeitai waspada dan mengawasi dengan cukup dekat proses proklamasi. Hatta mengubungi Laksamana Mayeda untuk menggunakan rumahnya sebagai tempat pertemuan para tokoh, ia pun setuju. Mayeda sendiri ikut bergabung dalam pertemuan, meskipun jam 2 pagi, ia berpamitan untuk istirahat. Soekarno dan Hatta bertemu dengan para anggota BPUPKI, seperti Soebardjo, Wikana, dan Sukarni menyusun naskah proklamasi. Setelah berdiskusi, pagi harinya, di depan rumah Soekarno, kalimat proklamasi dibacakan di depan grup kecil di halaman rumahnya. Hatta kemudian bergerak cepat dengan mengirim pesan pribadi kepada teman-temannya yang menjangkau penyiaran radio di seluruh Indonesia dan jejaring telegram. George McTurnan Kahin. Nationalism and Revolution in Indonesia. (Cornell, Cornell University Press, 1952)., p. 136-137
} 
seratus prosen. Suara rakjatlah jang memproklamirkan kemerdekaan, dan kekuasaan rakjat Indonesialah jang berpindah ke dalam tangan Negara Indonesia Merdeka, sehingga Rakjat Indonesialah jang menggugurkan dari kedua belah bahunja segala beban pendjajahan asing dan feodalisme nasional untuk mendjalankan Revolusi dan Peperangan Kemerdekaan, sebagai akibat penjorakan suara Rakjat jang membentuk dan mendapat kedaulatan negara tanggal 17 Agustus 1945 itu. Lemahkerasnya desakan musuh dan turun naiknja kemenangan kemerdekaan penuh, seperti diingini Rakjat dalam proklamasi 17 Agustus dan Deklarasi 22 Djuni 1945 itu. Keinginan selainnja daripada itu adalah semuanja djalan terpaksa menjimpang menudju perombakan dan terpaksa masuk kembali kedalam djurang penghinaan jang ditinggalkan Rakjat. Bangsa Indonesia memerdekakan dirinja pada tanggal 17 Agustus itu jalah djelasan ini memperingatkan wudjud dan udjung pangkal Keinginan Rakjat dengan pembentukan Republik Indonesia jang mulia raja itu., ${ }^{15}$

Proklamasi adalah sebuah momen sakral yang memproduksi kedaulatan. ${ }^{16}$ Sistem sosial yang dibangun oleh pemerintah kolonial masihlah sangat rasis. Bahkan Belanda pun masih berjuang hingga hari ini untuk melawan rasisme. ${ }^{17}$ Penindasan pada bangsa pribumi dari pemerintah kolonial cukuplah buruk dan masih eksploitatif, meskipun politik etis dibaharui terus-menerus. Dengan politik etis, sebenarnya keran politik demokrasi dibuka (Volksraad), sekolah dan perguruan tinggi dibangun, pegawai negeri juga diisi oleh bangsa pribumi, dst. Namun kesenjangan rasial masih saja muncul dan sungguh lebar. Yamin merujuk pada kalimat rakyat Murba. ${ }^{18}$ Sebuah kalimat yang menunjukan kondisi rakyat akar

\footnotetext{
15 Muhammad Yamin. Proklamasi dan Konstitusi Republik Indonesia. (Jakarta: 1951, Penerbit Djambatan)., p. X

${ }^{16}$ Hizkia Yosie Polimpung. Asal-Usul Kedaulatan: Telusur Psikogenealogis terhadap Hasrat Mikrofasisme Bernegara. (Jakarta: Penerbit Kepik, 2014). Dalam perkembangan berikutnya, gagasan tentang kedaulatan pun muncul dengan kritiknya, sebagai cikal bakal dari fasisme dan tirani yang memungkinkan pagi penguasa dan mayoritas lalim untuk membantai kelompok tertindas.

17 Philomena Essed \& Sandra Trienekens. Who Wants to Feel White? Race Ducth Culture and Contested Identities. Ethnic and Racial Studies. Vol. 31 No. 1 January 2008. P. 52-72. Meskipun ras Indonesia sekarang sudah keluar dari target group yang sering mendapat perlakuan rasis (walaupun masih tetap ada kasus yang masuk baik di pengadilan maupun komisi hak asasi manusia/ college de rechten van de mens), saat ini rasisme di Belanda berkutat pada pengungsi Siria, orang pendatang Maroko, Turki dan Afrika.

18 Yamin adalah pengagum berat Tan Malaka. Ia mengunakan kosakata Tan Malaka soal Murba ketimbang rakyat Marhein a la Soekarno. Hingga Tan Malaka pun memberikan pidatonya 'Sambutan Murba' (1948) dengan lantang berkata [..] Sampai saatnya sekarang Murba bangkit;
} 
rumput Indonesia. Yang sudah tidak mau lagi ditindas. Proklamasi adalah usaha awal untuk mengakhiri penghisapan kolonialisme itu. ${ }^{19}$

Yamin adalah orang yang loyal pada proklamasi. Mungkin ini juga yang menyebabkan ia menjadi orang yang paling diburu setelah Soekarno. ${ }^{20}$ Meskipun Yamin tak mendapat 'jatah' menteri, pada awal era kemerdekaan, ${ }^{21}$ kesetiaannya pada proklamasi dan Indonesia terlihat dalam tulisan-tulisannya dan sikap politiknya. Dalam bukunya Proklamasi dan Konstitusi Republik Indonesia (1951) Yamin memberi dukungan sepenuhnya pada proklamasi, bahkan menganggapnya setara dengan US Declaration of Independence (4 Juli 1776) dan Proklamasi Lenin dalam revolusi soviet (November 1917). ${ }^{22}$

Kolonialisme telah menyebabkan banyak kerugian pada rakyat Murba Indonesia. Sebanyak 200.000an orang kelaparan dan meninggal dalam perang Jawa, 70.000 orang tewas dalam perang Aceh, dan agresi militer 1947 dan 1948, begitu juga kerugian besar akibat tanam paksa (Cultuurstelsel). ${ }^{23}$ Maka Yamin

Murba berpikir; Murba bergerak; dan Murba memanggul beban revolusi ini menuju kepada masyarakat yang makmur, berdasarkan demokrasi dalam politik dan ekonomi. Bangunlah partai Murba, administrasi Murba dan laskar Murba di dalam pabrik, tambang, kebun dan desa! [...] Dengan granat di pinggang dan bambu runcing di tangan, kemerdekaan 100\% dapat dilaksanakan, karena $99 \%$ rakyat Murba masih bersemangat anti penjajahan! Lihat pada : https://www.marxists.org/indonesia/archive/malaka/1948-SambutanMurba.htm diunduh pada tanggal 12 Agustus 2016

${ }^{19}$ Lantaran proklamasi, Batavia setelah tanggal 17 Agustus 1945 sampai bulan-bulan berikutnya dikepung oleh balatentara Sekutu. Sebagai pusat gerakan nasionalis, Batavia akhirnya rela dilepaskan oleh para tokoh nasional dan hijrah ke Yogjakarta hingga penyerahan kedaulatan tanggal 27 Desember 1949. Jakarta masih menjadi kota berkarakter ganda, sebagai pusat pembangunan politik dan tumbuh kembangnya tradisi intelektual. Thomas Benjamin. Encyclopedia of Western Colonialism Since 1450. (Detroit: Macmillan Reference, 2007)., p. 124

${ }^{20}$ Sluiers over Indonesie. Helmondsch Dagblad, 25 September 1945.

21 Para menteri di era kemerdekaan, RAAA Wiranatakusumah, Menteri Luar Negeri Ahmad Subardjo, Menteri Kehakiman Prof. Dr. Supomo, Menteri Keuangan Mr. A.A. Maramis, Menteri Kemakmuran Ir Surachman Tjokroadisurjo, Menteri Pengajaran Ki Hajar Dewantara, Menteri Sosial Mr. Iwa Kusumasumantri, Menteri Keamanan Rakyat Supriyadi, Menteri Penerangan Mr. Amir Syarifuddin, Menteri Perhubungan dan Menteri Pekerjaan Umum Abicusno Cokrosujoso, Menteri Negara Wahid Hasyim, Dr. Mr. Amir, Mr. RM Sartono, dan Otto Iskandardinata.

22 Muhammad Yamin. Proklamasi dan Konstitusi Republik Indonesia. (Jakarta: 1951, Penerbit Djambatan)., p. 24

${ }^{23}$ Puluhan tahun Belanda tidak meminta maaf terhadap penjajahan yang dilakukannya di tanah nusantara setelah proklamasi kemerdekaan. Hingga akhirnya pada tahun 2000an perdana menteri Wim Kok menyeluarkan pernyataan permintaan maaf, meskipun agak kabur kata-katanya. Beberapa veteran mengkritik, kalaupun ada permintaan maaf, itu hanyalah permintaan kosong. Sebuah permintaan maaf tanpa reparasi dan kompensasi. Sampai sekarang, nasib permintaan maaf itu pun tak jelas. Kalau saja, semua pelanggaran HAM masa lalu diusut, pencarian kebenaran dibutuhkan untuk digali pada kolonialisme Belanda, pendudukan Jepang, peristiwa 65, Aceh, Papua, Timor Leste, dst, akan menjadi modal berharga dalam menyongsong masa depan. Berdamai dengan sejarah itu memang tidak mudah. Tapi harus diperjuangkan. Peter Baehr. Colonialism, Slavery, and the Slave Trade: A Dutch Perspective. Mark Gibney, Rhoda E. Howard-Hassmann and Jean-Marc 
menegaskan bahwa proklamasi adalah sebuah pertanda. Bahwa bangsa Indonesia tidak mau 'terpaksa masuk kembali kedalam djurang penghinaan.' Cukup sudah eksploitasi yang berlangsung cukup lama itu. Kolonialisme itu soal pendudukan manusia dan penghisapan sumber daya alam. ${ }^{24}$ Sudah saatnya bangsa Indonesia, pada waktu itu berdiri bebas tanpa pendudukan dan bisa menikmati kekayaan alamnya bersama anak cucunya.

Kerugian yang ditanggung Nusantara dan bangsa Indonesia sangatlah besar. Dimulai dari tanam paksa yang mengeksplotasi Indonesia disektor agroindustrialisme. ${ }^{25}$ Sampai rasisme yang berlangsung di ranah pendidikan, kesehatan, hukum, politik, sosial, pelayanan publik, kepegawaian, dst. ${ }^{26}$ Semua penderitaan kaum pribumi itu akan sirna dengan upaya proklamasi. Saat semua orang bisa duduk sama rata, berdiri sama tinggi.

Yamin percaya bahwa proklamasi sebagai sebentuk nasehat kepada bangsa Asing (Inggris dan Belanda) yang akan melakukan pendaratan di wilayah Indonesia, adalah pelanggaran konstitusional terhadap negara merdeka. Lanjut Yamin menilai dengan menembak, membunuh dan menangkap rakyat dan pemuda Indonesia, yang membuat pecahnya peperangan mempertahankan kemerdekaan. Pengorbanan pemuda Indonesia itu bagi Yamin sebagai sikap 'bersiap memikul segala kejakinan memegang kebenaran.' Proklamasi adalah kemerdekaan itu sendiri. Tak heran korban berjatuhan pun sangat banyak. Belum lagi soal pembantaian, beberapa pembunuhan massal dan pembumi-hangusan berlangsung, seperti di Rowogede pada tanggal 9 Desember 1947, kurang lebih 430an penduduk desa dibantai. ${ }^{27}$

Coicaud (eds), the Age of Apology: Facing Up to the Past. (Philadelphia, University of Pennsylvania Press, 2008)., p. 229-240

24 Barbara L. Stark. Colonialism and Landscape: Postcolonial Theory and Applications. Ethnohistory, Volume 51, Number 4, Fall 2004, pp. 656-860.

${ }^{25}$ Ajo Roersch van der Hoogte \& Toine Pieters. Science in the service of colonial agro-industrialism: the case of cinchona cultivation in the Dutch and Britis East Indies, 1852-1900. Studies in History and Philosophy of Biological and Biomedical Sciences 47 (2014) 12-22.

${ }^{26}$ Soepomo. Sistem Hukum di Indonesia. (Jakarta: Pradnya Paramita, 1981)., p. 34.

${ }^{27}$ Pembunuhan massal, pemerkosaan, dan pembumi hangusan sudah biasa dilakukan oleh tentara Jerman dan Jepang, namun para tentara Belanda jarang melakukannya, kecuali di beberapa peristiwa seperti di Rawagede. Abu Hanifah yang pada waktu itu adalah seorang tenaga medis menyaksikan secara langsung pembakaran desa-desa diseluruh wilayah sekitarnya. Tentara Belanda melakukan ekseskusi random terhadap para masyarakat sipil. Elizabeth Buthner. Europe after Empire: Decolonization, Scoeity, and Culture. Cambridge, Cambridge University Press, 2016., p. 92. 
Untuk mempertahankan proklamasi, pertempuran demi pertempuran dijalani oleh pemuda Indonesia, antara lain: pertempuran 10 November di Surabaya, Bandung Lautan Api, Pertempuran Medan Area, pertempuran lima hari di Semarang, pertempuran Ambarawa, dst. Korban berjatuhan dari kalangan pemuda Indonesia sangat banyak. Sama semangatnya dengan para pemuda, Yamin total mendukung proklamasi 17 Agustus 1945. Sebab kemerdekaan punya dua versi, menurut Indonesia sebagaimana dideklarasikan pada tanggal 17 Agustus 1945, sementara menurut Belanda saat Ratu Beatrix mengunjungi Indonesia harus singgah di Singapura untuk menghindari hari peringatan kemerdekaan Indonesia, sebab Belanda hanya mengakui 29 Desember 1949 Indonesia Merdeka. ${ }^{28}$

Sebab proklamasi bukanlah keinginan segelintir elite saja. Menurut Yamin, proklamasi adalah keinginan rakyat Indonesia. Soekarno menyusun kabinet dengan menteri-menterinya, menggunakan gedung-gedung peninggalan Belanda sebagai kantor pemerintahannya, menyusun komunikasi dengan beberapa negara, mengklaim mewakili $95 \%$ dari 70 -an juta rakyat Indonesia. ${ }^{29}$ Selanjutnya menurut Yamin, proklamasi bukanlah pepesan kosong, melainkan terdapat konstitusi yang tersusun yang menyertainya. Sah sebagai negara hukum yang berdaulat.

Suara jang mengutjapkan Proklamasi jalah suara keinginan Rakyat Indonesia; keinginan itu berdaulat dan berisi kemerdekaan penuh dan bulat. Sesuai dengan keadaan itu maka menurut Undang-Undang Dasar 1945 kedaulatan jang disuarakan dengan alat proklamasi dan jang mendorongkan menjusun Konstitusi 1945 itu jalah usaha kemerdekaan jang mendjadi inti-isi Kedaulatan di dalam tangan Rakjat Indonesia. $^{30}$

Rakyat sudah bosan barangkali dengan janji kolonialisme yang membujuk dengan beberapa perbaikan. Yamin menyebutkan hal ini sebagai pengejawantahan kekecewaan bersama atas kolonialisme. Terang saja, sejak VOC masuk ke Indonesia standar kualitas hidup mereka jauh ketimbang kaum pribumi. Bahkan pada zaman itu, orang pribumi maksimal umpamanya bekerja dalam sehari untuk

\footnotetext{
${ }^{28}$ Peter Baehr. Colonialism, Slavery, and the Slave Trade: A Dutch Perspective. Mark Gibney, Rhoda E. Howard-Hassmann and Jean-Marc Coicaud (eds), the Age of Apology: Facing Up to the Past. (Philadelphina: Unversity of Pennsylvania Press, 2008)., p. 229-240.

${ }^{29}$ Een Indonesische Quisling Regeering. Friesch Dagblad, 29 September 1945.

${ }^{30}$ Muhammad Yamin. Proklamasi dan Konstitusi Republik Indonesia. (Jakarta: 1951, Penerbit Djambatan)., p. 53
} 
satu pising nasi, pegawai VOC bisa memperoleh 25 kali dari apa yang didapat bangsa pribumi. ${ }^{31}$ Upah minimum yang timpang dari waktu ke waktu menyebabkan jurang kesenjangan.

Yamin dan para pemuda yang lain merasakan bahwa hidup dibawah bayangbayang kolonialisme sungguh menyengsarakan. Pribumi terlahir sebagai baboe dan warga kelas dua. Belum lagi kalau dalam setiap kolonialisme selalu saja ada 'motif terselubung.' Kafka menyebutnya hasrat erotisme dan eksotisme sebagai penyembahan pada seksualitas mengeksploitasi penduduk terjajah. ${ }^{32}$ Maka, dalam tradisi kolonial, perempuan-perempuan yang jadi gundik dan simpanan para tuan pejabat kolonial cukup akrap di dunia sastra. Perempuan-perempuan ini diantaranya sangat berkarakter dan populer dalam dunia literasi dengan sebutan Nyai. Beberapa Nyai terkenal yang diceritakan antara lain Nyai Dasima dan Nyai Ontosoroh. Nyai Dasima difilmkan pada tahun 1929 oleh sutradara Lie Tek Swie. ${ }^{33}$ Sementara Nyai Ontosoroh $^{34}$ dalam novelnya Pramudya Anantatoer. Dalam cerita dua Nyai ini punya kekuasaan harta berlimpah, lebih mujur ketimbang para Nyai yang hanya jadi tumbal nafsu. Tapi tetap saja mereka lemah tanpa ikatan dan status yang jelas.

Kembali sebaik apapun karakter sebuah kolonialisme, tetap saja wataknya berbentuk lintah dan penghisapan. Oleh karenanya, tak ada satu pun bangsa Indonesia yang bersumpah setia pada kolonialisme yang menindas. Bahkan progaganda dan agitasi, 'lebih baik mati ketimbang kembali dijajah,' berkobar

${ }^{31}$ Pim de Zwart. Globalization and the Colonial Origins of the Great Divergence. (Utrecht: Utrecht University, 1986), p. 121

32 Allen Thiher. Kafka's Travels: Exoticism, Colonialism and the Traffic of Writing. MFS Modern Fiction Studies, Volume 51, Number 3, Fall 2006, pp. 706-709. Eksotisme dan kolonialisme tidak bisa dipisahkan. Sudah tertanjam dalam diri para penahluk sebelum berangkat bepergian melalui kapal perang/ dagangnya untuk tidak hanya menundukan bangsa budak, tapi juga para perempuannya. Di tanah jajahan para penahluk itu punya aramah dan hasrat yang berlebihan, sehingga rindu dendam birahinya membuncah. Hal itu pun terlihat pada karya sastra dan lukisan kolonialisme.

${ }^{33}$ Njai Dasima dambil dari riwayat novel G Francis pada tahun 1896, yang menggambarkan kisah nyata kehidupan Nyari. Semula dari seorang gadis kampung Kuripan Bogor, ia diangkat jadi perempuan simpanan orang berkebangsaan Inggris, Edward William, pindah ke Batavia, sang Gadis bernama Dasima kaya raya. Saking kecantikan dan berlimpahnya hartanya, ia disukai banyak lelaki. ${ }^{34}$ Nyai Ontosoroh adalah sosok yang sangat berkarakter. Ia memimpin sebuah perusahaan besar, pertenakan, persawahan dan perkebunan yang cukup luas. Ia tak sekedar gundik dari Herman Mellema yang frustasi dan mabok-mabokan serta pergi entah kemana. Ia juga membaca banyak buku, berbahasa Belanda dengan lancar, dan anaknya bernama Annelies adalah gadis keturunan yang ayu berkepribadian Jawa. Ontosoroh juga sangat tegar dalam menghadapi rintangan, satu nasehat yang cukup memukau pada Minke (tokoh utama dalam Novel itu) adalah 'Orang boleh pandai setinggi langit, tapi selama ia tidak menulis, ia akan hilang di dalam masyarakat dan dari sejarah. Menulis adalah bekerja untuk keabadian.' 
melingking di emosi para pemuda. Begituhalnya Yamin, yang berusaha mendudukan segitiga penyangga kedaulatan: proklamasi, konstitusi dan suara rakyat.

\section{Pengkhianatan Versi Pemerintah Kolonial}

Bagi Yamin, proklamasi adalah 'tindakan penutup' perjuangan kemerdekaan Indonesia yang hampir dimulai sejak 40 tahun lama sebelumnya. ${ }^{35}$ Namun bagi pemerintah kolonial Belanda, proklamasi bersama ubo rampe-nya itu adalah sebuah tindakan pengkhianatan, terorisme dan separatisme. Dalam sebuah sidang parlemen tertanggal 10 Oktober 1945, proklamasi Indonesia di bahas dalam rangka menentukan arah kebijakan hukum kolonial untuk daerah-daerah jajahan Belanda. Salah satu sikap ditunjukan menteri Schermerhorn di dalam sidang menyatakan bahwa 'kesulitan-kesulitan ini muncul karena peristiwa baru (proklamasi) yang membuat goncangan pada pengaturan hukum kolonial.' Lebih lanjut, Schermerhorn menambahkan peristiwa yang terjadi di Indonesia sebagai 'hal yang menyakitkan.'36

Pihak pemerintah kolonial mengklaim sebenarnya banyak juga orang Belanda baik laki-laki maupun perempuan yang tinggal di Indonesia dan menganggapnya sebagai rumah sendiri. ${ }^{37}$ Sementara pihak Belanda mayoritas menyatakan hal yang serupa, reaksi marah. Menteri Logemann menyatakan tindakan para pemuda itu meneruskan mentalitas totaliter khas Jepang yang terus mengipas-kipas situasi politik yang terus memanas di Hindia. ${ }^{38}$ Van Poll anggota Parlemen Belanda juga dengan emosional menyatakan harus ada tindakan yang cepat di Jawa, untuk menyelamatkan perempuan dan anak-anak Belanda dari serdadu pemuda Indonesia yang kalab. ${ }^{39}$ Begitu halnya Meijerink anggota

\footnotetext{
${ }^{35}$ Muhammad Yamin. Proklamasi dan Konstitusi Republik Indonesia. (Jakarta: 1951, Penerbit Djambatan)., p. 16.

${ }^{36}$ Lebih lanjut, Menteri Schermerhorn menyatakan bahwa secara khusus mendukung argumentasi adanya pembaharuan pengaturan hukum kolonial daerah-daerah jajahan. Namun bukan serta merta menambah jumlah kelompok tokoh daerah jajahan di lembaga quasi-legislatif, lebih kepada seperti lembaga yang sudah ada sifatnya konsultasi untuk mempererat hubungan yang sudah terlanjur rusak karena tindakan separatis tokoh nasional fanatik. Handelingen Tweede Kamer 1945 No. 10, pada tanggal 10 Oktober 1945.

${ }^{37}$ L. De Jong. The Collapse of a Colonial Society: The Dutch in Indonesia during the Second World War. Vol. 206. Leiden: KITLV.

${ }^{38}$ Handelingen Tweede Kamer 1945 No. 16, pada tanggal 16 Oktober 1945.

${ }^{39}$ Handelingen Tweede Kamer 1945 No. 17, pada tanggal 17 Oktober 1945.
} 
Parlemen Belanda, yang akan menuduh Indonesia sebagai sarang komunis dan fasisme. Tindakan para pemuda yang dilakukan pada orang asing itu membangkitkan rasa jijik dunia internasional. ${ }^{40}$

Yamin dan tokoh pergerakan yang lain tetap bertahan. Bahkan apa yang digambarkan oleh Yamin, saat para pemuda Indonesia mempertahankan kemerdekaannya itu, bukanlah dalam sebuah kondisi perang yang seimbang. Yamin menggambarkan agresi militer Belanda sebagai sebuah pembantaian ketimbang adu kekuatan yang setara. Sebab senjata yang digunakan itu bukanlah perkakas perang yang terbarukan, melainkan bambu runcing yang melawan tank-raksasa, pesawat tempur dan tommygun. Sementara kapasitas Tentara Keamanan Rakyat (TKR) dan organisasi pemuda kemiliteran yang lain, belumnya terlatih dengan baik untuk menghadapi perang.

Kelihatanlah dibenua-kepulauan Austronesia perdjuangan bambu-runtjing melawan tank-raksasa, kapal terbang, tommygun, tampaklah pertempuran antara serdadu jang mendapat kemenangan dalam peperangan dunia dengan pemuda dan anak-Rakyat jang baru beladjar menembak dimedan peperangan. Rakjat tidaklah sadja berdjuang melainkan sewaktu-waktu bertindak apabila politik itu didjalankan dengan kebinbangan atau dengan kekurangan pertanggungan djawab apabila kurang bidjaksana dan mengutamakan pandangan sendiri diatas pendirian Rakjat jang sungguh-sungguh tetap menuntut kemerdekaan bulat semendjak 17 Agustus $1945 .{ }^{41}$

Yamin menilai pertempuran untuk mempertahankan proklamasi melawan agresi militer sungguh tidak berimbang. Pemuda Indonesia hanya mengandalkan aksi massa (dari sudut kuantitas tentara) dan medan yang sudah dikuasai. Mempraktekan gerilya seperti yang dioperasikan di kawasan Amerika Latin yang sudah akrab dengan hutan sebagai labirin benteng. Kolonialisme sesungguhnya adalah soal sistem dominasi. ${ }^{42}$ Saat sebuah pihak mendominasi diplomasi international, persenjataan tempur, dan saluran penyiaran radio serta media cetak.

\footnotetext{
${ }^{40}$ Handelingen Tweede Kamer 1945 No. 17, pada tanggal 17 Oktober 1945.

41 Muhammad Yamin. Proklamasi dan Konstitusi Republik Indonesia. (Jakarta: 1951, Penerbit Djambatan)., p. 26.

${ }^{42}$ Bruce Mazlish. Colonialism: A Theoritical Overview (Review). Journal of World History, Volume 10, Number 1, Spring 1999, pp. 232-234.
} 
Sementara sepanjang 1945 sampai 1949, semua perkakas didominasi oleh pemerintah kolonial. Situasi para pemuda semuanya terjepit.

Kolonialisme memang dikutuk di negeri tempat asalnya, daratan Eropa. Seperti yang diungkapkan oleh filsuf ternama Immanuel Kant, yang mengajukan kritik terhadap kolonialisme dan perbudakan karena tidak sesuai dengan moralitas universal dan konsep tentang hak. ${ }^{43}$ Namun kritik semangat pencerahan Eropa hanyalah dianggap sebagai gincu yang genit dalam perpolitikan sehari-hari. Praktek kolonialisme Belanda disokong juga dengan perbudakan dan perdagangan budak di Suriname dan Antillean. ${ }^{44}$ Sampai detik ini juga, Belanda masih mempunyai beberapa pulau ‘jajahan’ di Karibean, seperti pulai Bonaire, Saba, dan St. Eutatius.

Sidang parlemen Belanda terang saja mengutuk proklamasi. Pada pertemuan 17 Oktober 1945, dihadiri oleh 61 anggota parlemen seperti Ruijter, van der Sluis, van Braambeek, Tjalma, van der Zaal, van der Weijden, Droesen, Wendelaar, Bijlsma, van Lienden, de Wilde, dst dan satu pihak kementerian dalam negeri, luar negeri dan urusan daerah jajahan (van Overzeesche Gebeidsdeelen), anggota parlemen Meijerink menyatakan bahwa kelompok utama adalah kaum oportunis yang dimotori oleh Soekarno dan M. Hatta. Mereka sudah beberapa kali diasingkan dan tetap saja melakukan pembangkangan. Memanfaatkan kondisi menjadi pengkhinat dan antek Jepang. ${ }^{45}$

Selain Soekarno dan Hatta, nama Yamin dikantongi oleh Belanda, sebagai nama yang musti diburu. Nama yang masuk golongan nasionalisme fanatik. Kelompok yang tidak gentar seruan laksamana Mountbatten pimpinan angkatan perang sekutu menyerukan pendaratan ke Hindia dan melakukan pembersihan. ${ }^{46}$

Situasi paska proklamasi membuat para pemuda dan tokoh pergerakan makin terjepit. Setelah Sekutu mendarat, disertasi dengan merapatnya barisan kekuatan di Batavia dibawah Gubernur Jenderal J. Van Mook, kekuasaan pemerintah kolonial lambat laun pulih dan membesar. Beberapa daerah seperti

\footnotetext{
${ }^{43}$ Pauline Kleingeld. Kant's Second Thoughts on Colonialism. In Katrin Flikschuh and Lea Ypi. Kant and Colonialism: Historical and Critical Perspectives, Oxford University Press., 43-67.

${ }_{44}$ Peter Baehr. Colonialism, Slavery, and the Slave Trade: A Dutch Perspective. Mark Gibney, Rhoda E. Howard-Hassmann and Jean-Marc Coicaud (eds), the Age of Apology: Facing Up to the Past. (Philadelphia: Unversity of Pennsylvania Press, 2008)., p. 229-240.

${ }^{45}$ Handelingen Tweede Kamer 1945 No. 17, pada tanggal 17 Oktober 1945.

${ }^{46}$ Een Indonesische Quisling Regeering. Friesch Dagblad, 29 September 1945.
} 
Makasar, Ambon, dan Manado sudah dikuasai terlebih dahulu. ${ }^{47}$ Namun beberapa daerah masih sulit ditahlukan oleh Belanda, seperti Padang, Medan, dan Surabaya. Para pemuda melakukan perlawanan terhadap pasukan sekutu dan Belanda bersenjata lengkap. ${ }^{48}$ Pernyataan-pernyataan dan tulisan tokoh nasional, seperti Yamin pun diboikot oleh media internasional. ${ }^{49}$ Kendatipun demikian, keadaan semacam ini, lebih dipilih oleh kaum nasionalis. Ketimbang diombang-ambingkan dalam rejim kolonialisme dan kembali dijajah.

Dulu, Yamin sudah pernah mencoba melakukan pembaharuan melalui saluran dalam (Volksraad). Namun hasilnya nihil. Ia lebih percaya pada proklamasi. Yamin di Dewan Rakyat (Volksraad) pernah mengusulkan pemilu yang demokratis dan menawarkan konsep desentralisasi penuh, sebab pemilu dan desentralisasi yang beroperasi lebih sebagai hiasan. ${ }^{50}$ Namun usulannya itu sirna seperti embun pagi yang terkikis sinar mentari.

Di sektor yang lain, Yamin pernah mengusulkan revitalisasi pendidikan dan perguruan tinggi. Bangsa pribumi aksesnya cukup terbatas di sektor itu. ${ }^{51}$ Lagi-lagi usulan itu seperti rumah pasir yang roboh kena angin laut. Maka dengan mendukung proklamasi, Yamin kembali ke jalananan, mengutuk apa saja yang berbau kolonialisme. Dengan demikian, ia menjadi tokoh target dari pemerintah kolonial untuk 'diamankan.'

Proklamasi memang mendapatkan reaksi keras dari pihak pemerintah kolonial. Sebagai kelompok-kelompok nasionalis muda yang tidak mendukung berlangsungnya perdamaian paska perang dunia kedua. Dalam sebuah rapat yang akan menentukan revisi regulasi daerah jajahan pada tanggal 10 Oktober 1945 di Den Haag, sidang parlemen yang melibatkan 69 anggota legislatif dan Menteri Dalam Negeri (van Binnenlandsche Zaken) dan Menteri Social (van Sociale Zaken), menyoroti soal Indonesia baru-baru itu.

\footnotetext{
${ }^{47}$ Sluiers over Indonesie. Helmondsch Dagblad, 25 September 1945.

${ }^{48}$ Leuwarder Koerier. Bezetting van indie versneld. Pada tanggal 25 September 1945.

${ }^{49}$ Rustige Nacht in Batavia, Strijdend Nederland, pada tanggal 25 September 1945.

${ }^{50}$ Stadsgemeenteraad. Bataviasch nieuwblad pada tanggal 13 Februari 1942.

${ }^{51}$ Diverse Opmerkingen. Bataviasch nieuwsblad pada tanggal 28 Februari 1942. Dulu hanya bangsa priyayi atau orang yang punya duwit berlimpah sajalah yang mampu mengakses sekolah favorit. Sekolah hukum misalnya, didominasi oleh anak-anak bupati dan pejabat Gubernemen. Saat lulus, maupun pendaftaran, kebanyakan gelar mereka terpampang dalam papan pengumuman, dengan imbuhan 'Raden Mas, Raden Kanjeng, Mas, dst.' Sebuah simbol kepriyayian yang bisa menahlukan dunia pendidikan di masa kolonialisme Belanda.
} 
Dari sekian nada minor dan negatif yang mendominasi berjalannya sidang. Mereka yang tak suka kelakukan para tokoh pergerakan menyampaikan sumpah serapah yang tak karuan. Satu saja anggota Dewan keturunan Indo, yang mempunyai suara lain. Effendi nama anggota parlemen yang bersuara pelan, berbeda, namun degan susunan kata yang logis. Ia mengatakan bahwa 'Belanda sekarang berdiri di persimpangan sejarah. Akankah pergi ke jalan pembaharuan demokrasi dan modernitas kemajuan, atau terus menciptakan penderitaan dan reaksi yang konservatif [...] Demokrasi di Indonesia hendaknya diperhatikan, begitu juga di Suriname dan Curacao [...] hubungan harmonis, persamaan hak dan kerja sama sukarela perlu dipromosikan. ${ }^{52}$

Namun suara Effendi seperti burung prenjak yang terperangkap jaring. Ia dianggap suara yang fals dalam paduan suara parlemen saat itu. Sebaliknya, sidang parlemen pada tanggal 16 Oktober 1945 dengan pembicara tunggal Menteri Urusan Daerah Jajahan Logemann melaporkan bahwa sejak tanggal 15 Agustus 1945, agen rahasia Belanda mengawasi pergerakan tokoh nasional melalui komando laksamana Patterson yang ditugaskan di Batavia. Terdata paling tidak 2000an pemuda Indonesia bersenjata yang siap melakukan perlawanan. ${ }^{53}$ Itu sebabnya pemulihan ketertiban dan keamanan versi pemerintah kolonial Belanda sulit disusun.

Yang paling keras adalah sidang pada tanggal 17 Oktober 1945, yang diorasikan oleh van Poll berisikan letupan kemarahan politisi bermental majikan. Setelah ia berpidato menyampaikan kekuatiran terhadap 50.000 perempuan Belanda yang dikelilingi pemuda Indonesia bersenjata. Ia menyerukan supaya: pertama, ada tindakan tegas yang diambil untuk Soekarno dan pengikutnya; kedua,

\footnotetext{
${ }^{52}$ Handelingen Tweede Kamer 1945 No. 10, pada tanggal 10 Oktober 1945. Effendi lebih lanjut menhatakan bahwa peristiwa Indonesia itu tidak bisa semata-mata dipandang sebagai kesalahan dari pihak tokoh pergerakan semata, melainkan juga perlu ada evaluasi sampai dimanakah janji yang pernah diberikan oleh Ratu Belanda terhadap bangsa Indonesia. Keran-keran demokrasi seharusnya lebih dibuka lebar.

53 Handelingen Tweede Kamer 1945 No. 16, pada tanggal 16 Oktober 1945. Logemann juga menyampaikan bagaimana prihatinnya kondisi pemenjaraan para tawanan perang yang dilakukan oleh Jepang. Meskipun beberapa tempat, seperti di Bandung perawatan medis terhadap warga Belanda lumayan. Namun untuk bisa menguasai Batavia dan Bandung sekaligus butuh waktu yang lumayan lama, sebab di pedalaman para tokoh pergerakan sudah melakukan agitasi menyebabkan sebuah keadaan teror (een toestand van terreur) dan ketidak-nyamanan yang menyakitkan bagi Belanda (pijnlijke onveiligheid voor de Nederlanders veroorzaakt). Ini juga salah satu strategi Jepang untuk tidak mudah melepaskan daerah kekuasaannya, seperti yang mereka lakukan di Burma, Indocina, dan Filipina.
} 
menentukan sikap pemerintah belanda terhadap nasionalisme Indonesia yang separatis. ${ }^{54}$

Memang gesekan kolonialisme dan bangsa terjajah itu cukup menyita macam kepedihan. Belum lagi kolonialisme sebagai sebuah konsep adalah penomena universal dalam sejarah dunia. Kolonialisme bisa disebut sebagai lukisan yang penuh keburaman kolosal. ${ }^{55}$ Pada prakteknya juga, kolonialisme diikuti dengan gesekan antara pertarungan ras dan agama, bagaimana ras kulit putih menduduki ras kulit hitam dan kuning langsat. Begitu juga penyebaran agama Kristen, yang satu sisi juga membawa misi kemanusiaan, namun sisi yang lain adalah bawaan sang kolonial itu sendiri yang menggusur keyakinan lokal dan agama-agama seperti Hinduisme, Budhaisme, dst. ${ }^{56}$ Begitu juga dengan Belanda. Maka tak heran jika Logemann diatas menyebutkan revolusi Indonesia juga diwarnai kebencian terhadap ras kulit putih yang meluas.

Yamin menyebutkan bahwa proklamasi adalah awal dari revolusi sosial dan nasional Indonesia. Dengan adanya revolusi, meningkatlah persatuan dan kesatuan rakyat Indonesia menjadi bangsa-negara Indonesia yang merdeka. Sebuah konsep yang ditulis Yamin cukup apik. Yakni Kulturnation menjadilah staatsnation Indonesia. $^{57}$

\section{Berkonstitusi: Sah sebagai Negara}

Saat proklamasi berkumandang, konstitusi dirumuskan, saat itulah sebuah negara sah sebagai institusi yang mapan dan bebas. Yamin menyakini bahwa konstitusi tidak hanya sekumpulan sajak-sajak hukum. Bagi Yamin, konstitusi adalah kontrak sosial. Ia seakan-akan percaya bahwa Rousseau masih hidup dan ikut bergotong royong menyokong dasar teoritis konstitusi Indonesia. Dalam

\footnotetext{
${ }^{54}$ Handelingen Tweede Kamer 1945 No. 17, pada tanggal 17 Oktober 1945.

55 Barbara L. Stark. Colonialism and Landscape: Postcolonial Theory and Applications. Ethnohistory, Volume 51, Number 4, Fall 2004, pp. 656-860.

${ }^{56}$ Bruce Mazlish. Colonialism: A Theoritical Overview (Review). Journal of World History, Volume 10, Number 1, Spring 1999, pp. 232-234.

57 Muhammad Yamin. Proklamasi dan Konstitusi Republik Indonesia. (Jakarta: 1951, Penerbit Djambatan)., p. 127.
} 
perkembangannya, teori konstitusi memang banyak diterjemahkan sebagai sistem sosial. Konstitusi sehidup semati dengan masyarakatnya. ${ }^{58}$ Yamin menyebutnya proklamasi dan konstitusi sebagai sebuah fundamen dan basis politik.

[...] jalah suatu Konstitusi dan dalamnja tertulis sekumpul aturan jang menjusun kekuasaan politik dan masjarakat, medjamin dan menguatkan kemerdekaan negara dan warga. Perataan constitution beradal dari abad ke XVII, dan dalam kitab pudjangga Revolusi Perantjis JJ Rousseau jang bernama Contrat Social maka konstitui dinamai djuga lois oundamentales atau lois politique jang dapat disalin dalam bahasa kita: Undang-Undang Dasar dan Undang-Undang Kenegaraan. ${ }^{59}$

Yamin menganggap Rousseau sebagai pujangga yang melekat predikatnya dengan revolusi Perancis. Revolusi Perancis jelas sebuah momen heroik Eropa yang menjalar semangat ke seluruh belahan dunia. Dan, konstitusi adalah produk dari revolusi. Itulah mengapa konstitusi bukanlah teks biasa, melainkan sajak yang hidup (the living constitution). ${ }^{60}$ Dengan berkonstitusi, proklamasi bukanlah semata-mata seruan politis, melainkan pintu gerbang menuju modernitas negara hukum. ${ }^{61}$ Selain perkakas ideologis, konstitusi juga punya dimensi pragmantis, yakni sebagai medium kompromistis $^{62}$ negara unitaris Indonesia yang kaya fragmentasi kelompoknya.

\footnotetext{
${ }^{58}$ David Sciulli. Theory of societal constitutionalism. Foundations of a non-Marxist Critical Theory. (Cambridge: Cambridge University Press: 1992)., p. 151. Pola pengaturan sebuah konsep dalam konstitusi akan membangun integrasi sosialnya. Misalnya pengaturan konsep hak asasi manusia dalam sebuah konstitusi, semakin banyak konstitusi mengatur konsep tersebut, maka akan semakin banyak juga konsep-konsep kecil yang akan saling berinteraksi, semakin besar juga lembaga yang akan terlibat dalam mengimplementasikan konsep hak asasi manusia tersebut. Besar-kecilnya sebuah konsep diatur dalam konstitusi memperlihatkan fokus sebuah negara. Jika sebuah negara mengatur sebuah konsep dalam porsi yang besar, maka terlihat fokus pada masalah yang diatur itu juga konsentrasinya tinggi. Namun di satu sisi lain, sebuah konsep yang banyak diatur dalam konstitusi bisa berakibat kotraproduktif dengan harmonisasi sosial, karena dari pengaturan satu ke pengaturan yang lain bisa saling tumpang-tindih, konflik konseptual, dan resistensi ide-ide.

59 Muhammad Yamin. Proklamasi dan Konstitusi Republik Indonesia. (Jakarta: 1951, Penerbit Djambatan)., p. 70-71.

${ }^{60}$ Michel Coutu. Living Law: Reconsidering Eugen Ehrlich. Ecole de relations industrielles, Universite de Montreal and Onati Internasional Series in Law and Society, 2010)

61 Oren Ben-Dor. Constitutional Limits and the Public Sphere: A Critical Study of Bentham's Constitutionalism. London, Hart Publishing, 2000.

62 Daniel Bonilla Maldonado. The Multucultural Constitution: Chapter Three The 1991 Constitution, the Constitutional Court and the Tension between Individual Rights and Radical Difference. Multicultural Constitution in Onati IISL Basque Spain, 1991.
} 
Dengan demikian, konstitusi itu adalah sebuah kontrak peradaban negara hukum Indonesia. Tak heran, jika konstitusi juga dinilai sebagai perhimpunan moral sebuah bangsa, ${ }^{63}$ yang kelak menjadi dasar kehidupan bernegara bagi para elite dan rakyatnya. Dengan konstitusi, sebenarnya Yamin menyakini bahwa kemerdekaan Indonesia yang diucapkan pada tanggal 17 Agustus 1945 itu sudah sempurna dan komplet.

Pembentukan Negara Indonesia, jang merdeka, bersatu, berdaulat, adil dan makmur telah berlaku pada tanggal 17 Agustus 1945 itu. Akibat dari pada pelantikan Republik Indonesia dan permakluman kemerdekaan jalah membela Nusa dan Bangsa jang telah menduduki kemerdekaan seratus persen itu. Kedaulatan negara mengenai kemerdekaan-pemerintahan, kemerdekaan daerah, kemerdekaanrakjat, yang ketiganja terwudjud berisi penuh dan sempurna (complete independence $).{ }^{64}$

Yamin adalah penganut paham merdeka $100 \%$ yang digawangi oleh Tan Malaka. ${ }^{65}$ Selanjutnya ia mengkritik dengan keras hasil perjanjian linggar jati, yang menodai semangat proklamasi dan konstitusi negara yang berdaulat. Baginya, proklamasi dan konstitusi Indonesia, sudah cukup menjadi Indonesia bukan lagi Hindia-Belanda. Dan seluruh wilayah eks-jajahan Belanda, secara otomatis masuk

${ }^{63}$ Ronald Dworkin. Freedom's Law: The Moral Reading of the Amerian Constitutions. (Oxford: Oxford University Press, 1991). p. 8-11. Umpamanya moralitas kesetaraan, adalah hal yang terkandung dalam konstitusi Amerika. Dengan paham pragmatisme dan libertarian, politisi Amerika sadar bahwa hal yang terjadi pada James Madison 1789 tidak boleh berulang kembali. Apalagi kemudian diberlakukan Jim Crow Laws, yang membuat semuanya tersegregasi, mulai dari sekolah, rumah sakit, bahkan sampai jalan raya.

${ }^{64}$ Muhammad Yamin. Proklamasi dan Konstitusi Republik Indonesia. (Jakarta: 1951, Penerbit Djambatan)

${ }^{65}$ Meskipun konsep Merdeka $100 \%$ menurut Tan Malaka itu terbilang cukup detail, sampai pada pengawasan keluar masuknya barang-jasa, saat bangsa Pribumi sendiri bisa menentukan kebijakan arah industrialisasi sendiri. Seperti yang tergambarkan dalam tulisan Tan, pada dialog antara Pacul dan Godam, sebagai berikut: SI PACUL: Buat membatasi masuknya barang asing itu atau melarang masuknya sama sekali kita mesti $100 \%$ merdeka buat menguasai keluar-masuknya barang di Indonesia (ekspor dan impor). SI GODAM : Tepat, Cul! Merdeka 100\%! Kalau kita sudah merdeka $100 \%$ buat menguasai keluar masuknya barang asing itu, maka barulah kita bisa merdeka $100 \%$ menentukan "ARAH" industrialisasi di Indonesia, yakni menuju ke INDUSTRI BERAT seperti kilat. Baru sesudah kita mempunyai dan sanggup menyelenggarakan industri berat, baru kita bisa membikin sendiri alat kemakmuran dan alat pertahanan (seperti meriam, tank, kapal selam - terbang dsb). Barulah pula bisa dijamin Kemerdekaan Indonesia. Selama Indonesia belum mempunyai Industri Berat, selama itu pula INDONESIA MERDEKA terancam sangat Jiwa Kemerdekaannya. Lihat., https://www.marxists.org/indonesia/archive/malaka/1945-Politik.htm diakses pada 14 Agustus 1945 
dalam wilayah Republik, tanpa kecuali. Pun demikian dengan Irian Barat seharusnya.

Lebih lanjut, Yamin menyatakan bahwa kemerdekaan itu menyiratkan kedaulatan pemerintah, daerah dan rakyatnya. Sudah tidak ada lagi pemerintah Gubernemen dan kolonial yang mendekte. Sudah tidak ada neo-Leviathan rasisme ${ }^{66}$ yang meremehkan bangsa pribumi di panggung birokrasi dan ruang publik. Padahal semangat revolusi Prancis terbawa oleh Napoleon membabat daerah Belanda dan menancapkan konstitusinya, slogan persamaan (gelijkheid), kebebasan (vrijheid) dan persaudaraan (broederschap) tertanam dalam konstitusi Belanda pada tahun $1798 .^{67}$

Perkembangan konstitusi Belanda juga masih indah dalam teksnya. Konstitusi Belanda tahun 1806 menyebutkan prinsip kebebasan sosial (beginsel de maatschappelijke vrijheid). Namun dengan kata-kata yang indah itu, tak lantas membuat kolonialisme surut juga. Padahal Konstitusi 1806 menyebutkan persamaan hak (gelijke rechten) dan persamaan kewajiban (gelijke plichten). ${ }^{68}$ Konstitusi Belanda nampak indah dari teks, dalam perjalanan waktunya. Meskipun untuk daerah jajahan, tak semua diktum konstitusi diterapkan. Maka Yamin menolak negara boneka dan jajahan.

Yamin adalah orang yang optimis bahwa semangat proklamasi senantiasa tertiup dalam ubun-ubun konstitusi. Seperti yang ia katakan semangat proklamasi, yang juga tertuang dalam piagam Jakarta ${ }^{69}$ itu menjadi peramal akurat masa depan negara-bangsa Indonesia. Sebuah konstitusi yang hidup abadi, selamanya.

\section{PENUTUP}

\section{Kesimpulan}

\footnotetext{
66 Loï Wacquant. Marginality, Ethicity and Penality in the Neo-liberal City: An Analitic Cartography. Ethnic and Racial Studies 2014. Vol. 37, No., p. 1687-1711.

${ }^{67}$ Staatsregeling voor het Bataafsche Volk 1798. See., Proclamatie van 23 Maart 1798.

${ }^{68}$ Constitutie van het Koningrijk Holland 1806.

${ }^{69}$ Yamin masuk dalam penyusunan piagam Jakarta, atau biasa disebut tim kecil diluar BPUPKI atau PPKI. Namun ia nampaknya menganggap bahwa piagam Jakarta itu dalam kondisi sempurnanya adalah paska pengesahan sidang PPKI. Ia adalah seorang nasionalis, bukan pula penentang agama, bahkan seorang muslim. Namun lebih menyukai piagam jakarta yang sudah melebur dalam konstitusi 45.
} 
Proklamasi pada tanggal 17 Agustus 1945 dibahas di Parlemen Belanda pada tanggal 10 Oktober 1945, dengan 69 anggota legislatif yang hadir, bersama Menteri Dalam Negeri dan Menteri Urusan sosial mayoritas menentang kemauan pemudapemuda Indonesia untuk merdeka. Yamin bersikukuh, bahwa proklamasi dan konstitusi adalah dua perangkat hukum yang menandai adanya kedaulatan sepenuhnya Indonesia. Sebuah konstitusi, menurut Yamin adalah 'sekumpul aturan jang menjusun kekuasaan politik dan masjarakat, medjamin dan menguatkan kemerdekaan negara dan warga.' Itulah kenapa konstitusi adalah simbol dari kedaulatan. Sehingga Belanda, waktu itu tak bisa dengan mudah menggoyangkan keyakinan bahwa Indonesia belum merdeka. Sebab Indonesia sudah memproklamirkan diri dan berkonstitusi. Proklamasi dan konstitusi Indonesia ini juga diakui oleh banyak negara. Kalau dalam tradisi ilmu negara mengatakan syarat berdirinya negara adalah pemerintah, rakyat, wilayah dan pengakuan negara lain. Syarat lain yang perlu dilengkapi adalah proklamasi dan konstitusi, menurut Yamin.

\section{DAFTAR PUSTAKA}

Badiou, Alain. Metapolitics. (London: Verso, 2006).

Baehr, Peter. Colonialism, Slavery, and the Slave Trade: A Dutch Perspective. Mark Gibney, Rhoda E. Howard-Hassmann and Jean-Marc Coicaud (eds), the Age of Apology: Facing Up to the Past. (Philadelphia, University of Pennsylvania Press, 2008).

Ben-Dor, Oren. Constitutional Limits and the Public Sphere: A Critical Study of Bentham's Constitutionalism. London, Hart Publishing, 2000.

Buthner, Elizabeth. Europe after Empire: Decolonization, Scoeity, and Culture. Cambridge, Cambridge University Press, 2016.

Benjamin, Thomas. Encyclopedia of Western Colonialism Since 1450. (Detroit: Macmillan Reference, 2007).

Coutu, Michel. Living Law: Reconsidering Eugen Ehrlich. Ecole de relations industrielles, Universite de Montreal and Onati Internasional Series in Law and Society, 2010).

De Jong, L. The Collapse of a Colonial Society: The Dutch in Indonesia during the Second World War. Vol. 206. Leiden: KITLV.

Dworkin, Ronald. Freedom's Law: The Moral Reading of the Amerian Constitutions. (Oxford: Oxford University Press, 1991). 
Dworkin, Ronald. Justice in Robes. (Harvard: The Belkpan Press of Harvard University Press, 2006).

Essed, Philomena \& Trienekens, Sandra. Who Wants to Feel White? Race Ducth Culture and Contested Identities. Ethnic and Racial Studies. Vol. 31 No. 1 January 2008., p. 52-72.

Kahin, George McTurnan. Nationalism and Revolution in Indonesia. (Cornell, Cornell University Press, 1952).

Kleingeld, Pauline. Kant's Second Thoughts on Colonialism. In Katrin Flikschuh and Lea Ypi. Kant and Colonialism: Historical and Critical Perspectives, Oxford University Press.

Mazlish, Bruce. Colonialism: A Theoritical Overview (Review). Journal of World History, $\quad$ Volume 10, Number 1, Spring 1999, pp. 232-234.

Mazlish, Bruce. Colonialism: A Theoritical Overview (Review). Journal of World History, $\quad$ Volume 10, Number 1, Spring 1999, pp. 232-234.

Maldonado, Daniel Bonilla. The Multucultural Constitution: Chapter Three The 1991 Constitution, the Constitutional Court and the Tension between Individual Rights and Radical Difference. Multicultural Constitution in Onati IISL Basque Spain, 1991.

Sciulli, David. Theory of societal constitutionalism. Foundations of a non-Marxist Critical Theory. (Cambridge: Cambridge University Press: 1992).

Soepomo. Sistem Hukum di Indonesia. (Jakarta: Pradnya Paramita, 1981).

Stark, Barbara L. Colonialism and Landscape: Postcolonial Theory and Applications. Ethnohistory, Volume 51, Number 4, Fall 2004, pp. 656-860.

Thiher, Allen. Kafka's Travels: Exoticism, Colonialism and the Traffic of Writing. MFS Modern Fiction Studies, Volume 51, Number 3, Fall 2006, pp. 706-709.

Polimpung, Hizkia Yosie. Asal-Usul Kedaulatan: Telusur Psikogenealogis terhadap Hasrat Mikrofasisme Bernegara. (Jakarta: Penerbit Kepik, 2014).

Yamin, Muhammad. Proklamasi dan Konstitusi Republik Indonesia. (Jakarta: 1951, Penerbit Djambatan).

Wacquant, Loïc. Marginality, Ethicity and Penality in the Neo-liberal City: An Analitic Cartography. Ethnic and Racial Studies 2014. Vol. 37, No., p. 16871711.

Waldron, Jeremy. Ronald Dworkin: An Appreciation. New York University School of Law Paper Working No. 13-19., Juli 2013.

Zwart, Pim de. Globalization and the Colonial Origins of the Great Divergence. (Utrecht: Utrecht University, 1986). 